\title{
Editorial
}

\section{Is the tide turning?}

In this issue of the Journal, Cohen, Wade and Woodward report on a national survey of anaesthetists undertaken to determine the effect of liability concerns on the practice of anaesthesia. The data collected and the conclusions reached by the authors merit the careful attention not only of those with a special interest in medico-legal affairs but of all practising anaesthetists and particularly those involved in clinical teaching.

It is probably not surprising that anaesthetists' answers to a questionnaire on liability matters should reflect a significant level of concern about the risk of a malpractice lawsuit. During the decade of the seventies when legal actions against doctors began to increase in frequency and severity, those practising anaesthesia saw themselves and were seen by others as the cause of much of the most costly malpractice litigation. Their specialty appeared in the vanguard of what was perceived by many to be a progressively more serious malpractice problem in Canada.

In more recent years the focus of malpractice litigation has changed somewhat. However, anaesthetists along with practitioners in other medical fields continue to be aware of their vulnerability to lawsuits. Whether this awareness and consequent concerns have contributed directly and significantly to changes in patterns of practice or whether such changes result from other factors may be difficult to assess. Attempts to quantify the financial impact of so-called defensive medicine have never been particularly convincing. It is possible that identifying reasons for changes in practice patterns may be equally complex.

Those who have knowledge of liability matters during the last two decades will be aware there has been a significant change in the patterns of litigation against anaesthetists in this country. No longer does anaesthesia fall within the highest CMPA risk rated group for liability protection purposes as once it did.

More than a decade ago, each year, the CMPA would learn of difficulties arising from faulty anaesthetic equipment or of anaesthetic disasters directly attributable to lack of standardization of anaesthetic machines. It would be overly optimistic to suggest that mishaps of this kind

The Canadian Medical Protective Association, Ottawa.

\section{F. Norman Brown MD, R.W. McIntyre MD}

will never again occur. However, litigation from this source in recent years has become almost non-existent. We can speculate that this is in part the result of the work of those in the profession who have concerned themselves with standardization of equipment and collaboration with manufacturers. Perhaps concerns about liability stimulated these initiatives but it seems more likely that they were simply the result of advancing technology and considerations of patient safety.

In the early seventies, experience with litigation forced the CMPA to warn members repeatedly about attempting to monitor more than one anaesthetized patient without appropriate professional assistance. When a mishap occurred in these circumstances, when a patient suffered hypoxic brain damage and a legal action was started, it could become very difficult indeed to refute allegations of negligence. The Association's experience in more recent years suggests that this indefensible pattern of practice rarely if ever is followed.

In the Association's view this change from an undesirable practice pattern is likely due to the educational efforts of various professional groups including the CMPA itself. In particular it is due to the development and updating by the CAS of the Guidelines for Minimal Standards of Practice of Anaesthesia. These guidelines, circulated throughout the profession, have influenced changing patterns of practice. Their formulation was stimulated by a desire to improve the quality of anaesthetic practice, and not primarily because of litigation concerns.

That the vast majority of respondents to the Cohen questionnaire have increased their monitoring of patients during the last five years is of particular interest. This increased attention to monitoring is probably important when considered in the context of what appears to be an improvement in the medico-legal climate for anaesthetists in Canada. Over this time there has been a decline in the incidence of legal actions resulting from those disastrous accidents which were of concern to anaesthetists in the seventies. Although the reasons given by the respondents for their greater emphasis on monitoring includes liability concerns, they also cite as equally important influences continuing medical education and specialist society recommendations.

The CMPA has always felt that the overall standard of anaesthetic care in Canada has been of high quality. 
Nevertheless, the increasing complexity of anaesthetic techniques and of surgical procedures as well as higher patient expectations dictate the need for continuing vigilance and the sustaining of educational efforts if the improved liability picture is to be maintained. It was gratifying to learn from the survey that the CMPA Information Letter provides anaesthetists with their main source of information about liability issues. This suggests a defence organization has an important educational role to fulfill and will encourage further efforts in this direction.

Caution should be exercised in drawing the inference that fear of litigation is a suitable quality control measure. A multiplicity of factors requires consideration when assessing questionnaire results relating to personal involvement in lawsuits. Therefore it would be misleading to reach conclusions about regional differences in litigation patterns on the basis of the study.

The survey by Cohen, Wade and Woodward in our view is most useful in identifying where educational efforts in the past have been effective and in pointing to targets for further educational initiatives. Maintaining and improving the quality of anaesthetic practice will continue to serve best the interests of patients and anaesthetists; reducing vulnerability to lawsuits will be a byproduct.

\section{La vague est-elle en train de tourner?}

Dans ce numéro du Journal, Cohen, Wade et Woodward rapportent le résultat d'une étude nationale conçue pour déterminer l'influence du souci de la responsabilité légale sur la pratique anesthésique. Les données recueillies et les conclusions atteintes par les auteurs méritent une attention particulière de la part non seulement de ceux qui ont un intérêt particulier dans les affaires médico-légale mais aussi de tous les anesthésistes pratiquant et particulièrement ceux impliqués dans l'enseignement clinique.

Il n'est probablement pas surprenant que les réponses des anesthésistes à un questionnaire sur les responsabilités reflètent un degré de préoccupation élevé concernant le risque de poursuite légale. Durant les années soixante-dix lorsque les poursuites légales envers les médecins ont commencé à augmenter en fréquence et en sévérité les anesthésistes pratiquant se sont vus et furent aussi pointés par d'autres comme étant la cause de plusieurs litiges coûteux. Leur spécialité apparaissait en tête de ce qui était perçu par plusieurs comme étant un problème de mauvaise pratique de plus en plus sérieux au Canada.

Plus récemment la tension sur les litiges de mauvaise pratique a changé quelque peu. Cependant, les anesthésistes comme les praticiens dans les différentes branches médicales continuent d'être conscients de leur vulnérabilité judiciaire. Il est difficile d'évaluer si cette conscience et par conséquence cette préoccupation a contribué directement et significativement à changer le mode de pratique ou si ces changements sont des résultats d'autres facteurs. Les tentatives de quantifier l'impact financier de ce que l'on appelle «une médecine défensive» n'a jamais été particulièrement convaincant. Il est possible que l'identification des raisons du changement de la pratique soit aussi complexe.

Ceux qui sont versés en matière de responsabilité durant les dix derniéres années sont conscients qu'il y a eu un changement significatif dans le «pattern» de litiges contre les anesthésistes dans ce pays. Pour l'Association Canadienne de Protection Médicale (CMPA) l'anesthésie ne figure plus comme dans le passé dans le groupe à risque élevé.

Cela fait plus que dix ans que chaque année l'Association Canadienne de Protection Médicale recueille les problèmes dûs à un équipement anesthésique défectueux ou un désastre anesthésique directement attribuable au manque de standardisation des machines anesthésiques. Il serait très optimiste de suggérer que des incidents de ce genre ne surviendront plus jamais. Cependant les litiges concernant l'équipement d'anesthésie sont devenus presque inexistants. On peut spéculer que ceci est en partie dô au travail de professionnels qui se sont occupés de standardiser l'équipement en collaboration avec le manufacturier. La préoccupation légale a peut-être stimulé ces initiatives mais il serait plus probable qu'ils soient simplement le résultat d'une amélioration technologique et un souci pour la sécurité du patient.

Au début des années soixante-dix, les litiges ont forcé l'Association Canadienne de Protection Médicale d'avertir les membres à plusieurs reprises concernant la surveillance de plus qu'un patient anesthésié sans assistance professionnelle appropriée. Quand un accident survenait dans ces circonstances, quand le patient a souffert d'hypoxie cérébrale et qu'une poursuite est commencée, il serait extrêmement difficile de nier les allégations de négligence. L'expérience de l'Association suggère récemment que ce mode de pratique est rarement suivi.

Du point de vue de l'Association, cet éloignement des modes de pratique indésirables est probablement dû aux efforts d'enseignement de différents groupes professionnels incluant l'Association Canadienne de Protection Médicale. En particulier il est dû au développement et à la mise à jour par la Société Canadienne des Anesthésistes 
des directives pour des normes de pratique en anesthésie. Ces directives circulées pour toute la profession ont influencé le changement de pratique. Leur conception était issue d'un désir d'améliorer la qualité de la pratique anesthésique et non principalement à cause d'une crainte de litiges.

$\mathrm{Du}$ fait que la vaste majorité des répondants au questionnaire de Cohen ont augmenté leur moyen de surveillance des patients durant les cinq dernières années est particulièrement intéressant. Cette augmentation croissante de la surveillance est probablement importante quant elle est considérée dans le contexte d'une amélioration du climat médico-légal pour les anesthésistes au Canada. Pendant ce temps il y avait une diminution de l'incidence des procédures légales suite à des acidents anesthésiques désastreux qui étaient communs dans les années soixante-dix. Même si les raisons données par les répondants justifiant leur plus grande emphase sur le monitoring incluent la crainte de poursuite, ils ont aussi mentionné comme également important l'influence de l'éducation médicale continue et les recommandations de la Société des Spécialistes.

L'Association Canadienne de Protection Médicale a toujours senti qu'en général les normes des soins anesthésiques au Canada étaient de grande qualité. Néanmoins l'augmentation de la complexité des techniques anesthésiques et des procédures chirurgicales ainsi que l'expectative croissante des patients dictent la nécessité pour une vigilance continue et des efforts soutenus d'enseignement si l'amélioration de l'état de responsabilité doit se maintenir. Il est gratifiant d'apprendre que dans ce questionnaire la Lettre d' information publiée par l'Association Canadienne de Protection Médicale constitue pour les anesthésistes une source importante d'information sur les problèmes de responsabilité. Ceci suggère qu'une organisation de défense a un rôle éducationnel important à remplir et encouragera d'autres efforts dans cette direction.

Une précaution doit être considérée concernant l'inférence que la peur de litiges est une mesure adéquate du contrôle de la qualité de l'acte professionnel. Une multiplicité de facteurs méritent considération quand on évalue les résultats d'un questionnaire concernant l'implication personnelle dans des poursuites. Ainsi il serait déroutant d'atteindre des conclusions concernant des différences régionales dans le "pattern»' de litiges se basant sur cette étude.

Le sondage de Cohen, Wade et Woodward à notre point de vue est très utile pour identifier les points où les efforts éducationnels ont été efficaces et pour définir des buts pour d'autres initiatives d'enseignement. Le maintien et l'amélioration de la qualité de la pratique anesthésique continuera à servir les intérêts des patients et des anesthésistes, la réduction de la vulnérabilité aux poursuites sera un sousproduit. 